\title{
HL-A antigens and the sicca syndrome
}

\author{
R. D. STURROCK, BIANCA A. CANESI, HEATHER M. DICK, AND W. CARSON DICK \\ From the Centre for Rheumatic Diseases and Department of Clinical Immunology, Royal Infirmary, Glasgow
}

The recent interest in the HL-A typing as applied to the rheumatic diseases (Brewerton, Caffrey, Hart, James, Nicholls, and Sturrock, 1973; Schlosstein, Terasaki, Bluestone, and Pearson, 1973) has prompted us to investigate the possible association of an HL-A antigen in patients with the 'sicca syndrome', viz. keratoconjunctivitis sicca and xerostomia. Birch, Bunim, and Bloch (1963) in a clinical and serological study of fourteen patients with Sjögren's syndrome and 121 blood relatives have demonstrated familial aggregation of possible or probable rheumatoid arthritis, decreased lacrimal secretion, and abnormal circulating antibodies. They presented evidence to suggest that this may be due to heredity rather than environmental factors. The peculiar association of the 'sicca syndrome' with malignant lymphoreticular neoplasms (Talal, Sokoloff, and Barth, 1967; Azzopardi and Evans, 1971) is also interesting in view of the association between lymphoma and HL-A5 and W18 (Zervas, Delamore, Israëls, 1970).

\section{Material and methods}

To assess whether these observations could be explained by a particular HL-A antigen, we have studied 21 patients (age range 24 to 86 years; mean 61) with the sicca syndrome of whom nineteen had a depressed salivary flow rate and sixteen a positive labial gland biopsy (Whaley, Chisholm, Downie, Dick, and Williamson, 1968). Rheumatoid factor was present in the serum of sixteen patients) ten had a positive antinuclear factor (titre 1:1-61:256), and six complained of joint pains. HL-A typing was performed using a modification of the technique of KissmeyerNielsen and Kyerbye (1967).

\section{Results}

The results are shown in Tables I and II. The frequencies of the antigens occurring in the patient groups do not markedly differ from the frequencies observed in the general population of the West of Scotland tested since 1969. Statistical evaluation using the $\chi^{2}$ test did not show any significant differences between the two groups. Although the patient sample size is small, it is clear that there is no HL-A antigen showing a striking association with the sicca syndrome.

We wish to acknowledge the financial support of the Arthritis and Rheumatism Council of Great Britain.

Table I $H L-A$ antigen frequencies. First locus antigens

\begin{tabular}{|c|c|c|c|c|c|c|}
\hline \multirow[t]{2}{*}{ Antigens } & \multicolumn{3}{|c|}{ Random } & \multicolumn{3}{|c|}{ Sicca syndrome } \\
\hline & $\begin{array}{l}\text { No. } \\
\text { tested }\end{array}$ & $\begin{array}{l}\text { No. } \\
\text { positive }\end{array}$ & $\begin{array}{l}\text { Percentage } \\
\text { frequency }\end{array}$ & $\begin{array}{l}\text { No. } \\
\text { tested }\end{array}$ & $\begin{array}{l}\text { No. } \\
\text { positive }\end{array}$ & $\begin{array}{l}\text { Percentage } \\
\text { frequency }\end{array}$ \\
\hline HL-Al & 597 & 184 & $30 \cdot 8$ & 21 & 11 & $52 \cdot 38$ \\
\hline HL-A2 & 597 & 285 & $47 \cdot 73$ & 21 & 13 & $61 \cdot 90$ \\
\hline HL-A3 & 597 & 135 & $22 \cdot 61$ & 21 & 3 & $14 \cdot 28$ \\
\hline HL-A9 & 597 & 107 & $17 \cdot 92$ & 21 & 7 & $33 \cdot 3$ \\
\hline HL-A10 & 597 & 41 & $6 \cdot 86$ & 21 & 2 & $9 \cdot 52$ \\
\hline HL-A11 & 597 & 51 & $8 \cdot 54$ & 21 & 2 & $9 \cdot 52$ \\
\hline W28 & 597 & 42 & $7 \cdot 03$ & 21 & 1 & $4 \cdot 76$ \\
\hline ‘W19' & 487 & 68 & 13.96 & 21 & 1 & $4 \cdot 76$ \\
\hline
\end{tabular}


Table II HL-A antigen frequencies. Second locus antigens

\begin{tabular}{|c|c|c|c|c|c|c|}
\hline \multirow[t]{2}{*}{ Antigens } & \multicolumn{3}{|c|}{ Random } & \multicolumn{3}{|c|}{ Sicca syndrome } \\
\hline & $\begin{array}{l}\text { No. } \\
\text { tested }\end{array}$ & $\begin{array}{l}\text { No. } \\
\text { positive }\end{array}$ & $\begin{array}{l}\text { Percentage } \\
\text { frequency }\end{array}$ & $\begin{array}{l}\text { No. } \\
\text { tested }\end{array}$ & $\begin{array}{l}\text { No. } \\
\text { positive }\end{array}$ & $\begin{array}{l}\text { Percentage } \\
\text { frequency }\end{array}$ \\
\hline HL-A5 & 597 & 31 & $5 \cdot 19$ & 21 & 0 & 0.00 \\
\hline HL-A7 & 597 & 177 & $29 \cdot 64$ & 21 & 5 & $23 \cdot 8$ \\
\hline HL-A8 & 597 & 186 & $31 \cdot 15$ & 21 & 8 & $38 \cdot 09$ \\
\hline HL-A12 & 597 & 199 & $33 \cdot 33$ & 21 & 8 & 38.09 \\
\hline HL-A13 & 597 & 24 & $4 \cdot 02$ & 21 & 0 & 0.00 \\
\hline W5 & 494 & 40 & 8.09 & 21 & 3 & $14 \cdot 28$ \\
\hline W10 & 516 & 49 & $9 \cdot 49$ & 21 & 4 & $19 \cdot 04$ \\
\hline W14 & 502 & 40 & $7 \cdot 96$ & 21 & 1 & $4 \cdot 76$ \\
\hline W15 & 610 & 48 & $7 \cdot 86$ & 21 & 0 & 0.00 \\
\hline W16 & 422 & 15 & $3 \cdot 55$ & 21 & 3 & $14 \cdot 28$ \\
\hline W17 & 491 & 33 & $6 \cdot 72$ & 21 & 3 & $14 \cdot 28$ \\
\hline W18 & 399 & 21 & $5 \cdot 26$ & 21 & 2 & $9 \cdot 52$ \\
\hline W21 & 477 & 12 & $2 \cdot 51$ & 21 & 0 & $0 \cdot 00$ \\
\hline W22 & 495 & 17 & $3 \cdot 43$ & 21 & 0 & 0.00 \\
\hline W27 & 509 & 45 & $8 \cdot 84$ & 21 & 2 & $9 \cdot 52$ \\
\hline
\end{tabular}

\section{References}

Azzopardi, J. G., AND Evans, D. J. (1971) J. clin. Path., 24, 744 (Malignant lymphoma of parotid associated with Mikulicz disease, benign lymphoepithelial lesion)

Brewerton, D. A., Caffrey, M., Hart, F. Dudley, James, D. C. O., Nicholls, A., And Sturrock, R. D. (1973) Lancet, 1, 904 (Ankylosing spondylitis and HL-A27)

BurCh, T. A., Bunim, J. J., AND Bloch, K. J. (1963) 'Studies on relatives of patients with Sjögren's syndrome', in 'The Epidemiology of Chronic Rheumatism', ed. J. H. Kellgren, M. R. Jeffrey, and J. Ball, p. 267. Blackwell, Oxford

KisSMEYER-NielSEN, F., AND KJERBYE, K. E. (1967) 'Lymphocytotoxic microtechnique. Purification of lymphocytes by flotation', in 'Histocompatibility Testing', Report of a Conference and Workshop, Torino and St. Vincent, Italy, 1967, ed. E. S. Curtoni, B. L. Mattiuz, and R. M. Tosi, pp. 381-383. Munksgaard, Copenhagen

Schlosstein, L., Terasaki, P. I., Bluestone, R., and Pearson, C. M. (1973) New Engl. J. Med., 288, 704 (High association of HL-A Antigen, W27, with ankylosing spondylitis)

Talal, N., Sokoloff, I., AND BaRTh, W. F. (1967) Amer. J. Med., 43, 50 (Extra-salivary lymphoid abnormalities in Sjögren's syndrome (Reticulum cell sarcoma 'pseudolymphoma' macroglobulinemia))

Whaley, K., Chisholm, D. M., Downie, W. W., Dick, W. C., And Williamson, J. (1968) Acta rheum. scand., 14, 298 (Lymphocytic sialadenitis in the buccal mucosa in Sjögren's disease, rheumatoid arthritis, and other arthritides)

Zervas, J. D., Delamore, I. W., AND IsRaËLS, M. C. G. (1970) Lancet, 2, 634 (Leucocyte phenotypes in Hodgkin's disease) 